\title{
Trichoderma: a Most Common Biofertilizer with Multiple Roles in Agriculture
}

\author{
Ranveer Kumar Kamal*1, Victor Athisayam², Yogendra Singh Gusain ${ }^{3}$ and Vivek Kumar ${ }^{4}$ \\ ${ }^{1}$ Quality Control, Terra Agro Biotech Pvt. Ltd., Vaishali Nagar, India \\ ${ }^{2}$ Centre for Plant Molecular Biology, Madurai Kamaraj University, India \\ ${ }^{3}$ College of Forestry, Uttarakhand University of Horticulture and Forestry, India \\ ${ }^{4}$ Department of Botany, M.B.P.G. Government College, India
}

Received: May 17, 2018; Published: May 24, 2018

*Corresponding author: Ranveer Kumar Kamal, Quality Control, Terra Agro Biotech Pvt. Ltd., Vaishali Nagar, Jaipur, 302021 Rajasthan, India

\section{Introduction}

The genus Trichoderma comprises a great number of fungal strains that colonize plants roots as a symbiont and have properties to stimulate plant growth and development [1]. Trichoderma species have long been recognized as agents for the control of plant disease and for their ability to increase plant growth and development. The use of Trichoderma as a biological agent could be cost-reducing and effective strategy. Many works on Trichoderma focusing on their abilities to alleviate abiotic stress is going on, however the specific knowledge of mechanisms regarding the abilities to control multiple plant abiotic stress factors has yet to be covered. There are several molecular biology approaches like genetic engineering, recombinant DNA technology etc. being used at biochemical level for the improvement and development of Trichoderma strains.

\section{Facts to know about Trichoderma}

Trichoderma naturally present in most soils. Commercialization of Trichoderma biofertilizer raises hope in farmers. Trichoderma used in almost all type of crops, with or without any amendments, but if Trichoderma biofertilizer is used as an amendment with compost may gives better results than any other fertilizer. It minimizes the use of traditional fertilizer based on NPK. It improves the uptake of micronutrients to plants such as $\mathrm{Cu}, \mathrm{Zn}, \mathrm{Fe}, \mathrm{Na}$ etc. and helps in solubilization of phosphate in soil and available to plants. Trichoderma improves overall plant health, by creating a positive environment with symbiotic relationship with plants and releases various types of secondary metabolites including, growth hormones, endochitinase, proteolytic enzymes [2] and benefits the plants by taking advantage of plant-microbe interactions. The biofertilizer also used as soil conditioner, improves the population of plant beneficial microorganisms in soil. It helps in mitigating green house gases like Carbon dioxide and methane, a great cause for global warming (CSIR-India).
In the present market, many Trichoderma species is being used as biofertilizer with specific feature such as T. harzianum, T. viride, T. reesi, T. polysporum, T. koningii etc, but T. harzianum and $\mathrm{T}$. viride is most commonly used biofertilizer. T. harzianum improves plant tolerance to environmental stress, and mineral absorption [3]. T. viride improves seed germination rate, when applied for seed treatment. Trichoderma biofertilizer effective against many pathogenic fungi i.e. Fusarium, Rhizoctonia, Pythium, Schlerotinia, Verticillium, Alternaria, Phytopthrora and other fungi $[4,5]$.

\section{Application}

a) Seed treatment - 8 to $10 \mathrm{gm}$ per $50 \mathrm{ml}$ water for $1 \mathrm{~kg}$ seeds

b) Seedling - 250- 500 gm per 50 Liter of water

c) Soil Drenching - 1-2 kg per Acre (200 Liter of water)

\section{Formulation}

Trichoderma formulations are available in many brand names, with minimum 2 × 109 or 3 × 106 cfu per gram in carrier material.

\section{Recommendation}

The Trichoderma biofertilizer can be used in many crops such as groundnut, cotton, wheat, tobacco, Bengal gram, brinjal, sugarcane, eggplant, red gram, banana, tomato, sugarbeet, chillies, potato, soybean, citrus, cauliflower, onion, peas, sunflower, coffee, tea, ginger, turmeric, pepper, betel vine, cardamom etc.

\section{Compatibility}

Trichoderma is compatible with Organic manure, and with biofertilizers like Azospirillum, Rhizobium, Bacillus Subtilis and Phosphobacteria. 


\section{Precautions}

Don't use trichoderma in dry soil, moisture is essential for its growth and survivability. Try not to use chemical fungicide after application of Trichoderma biofertilizer for 4-5 days.

\section{References}

1. Harman GE, Howell CR, Viterbo A, Chet I, Lorito M (2004) Trichoderma species-opportunistic, avirulent plant symbionts. Nat Rev Microbiol 2: 43-56.

2. Benítez T, Rincón A, Carmen Limón M, Codón AC (2004) Biocontrol mechanisms of Trichoderma strains. Intl Microbiol 7: 249-260.

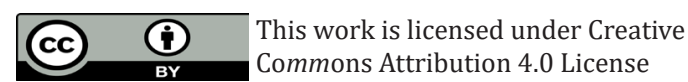

Submission Link: https://biomedres.us/submit-manuscript.php

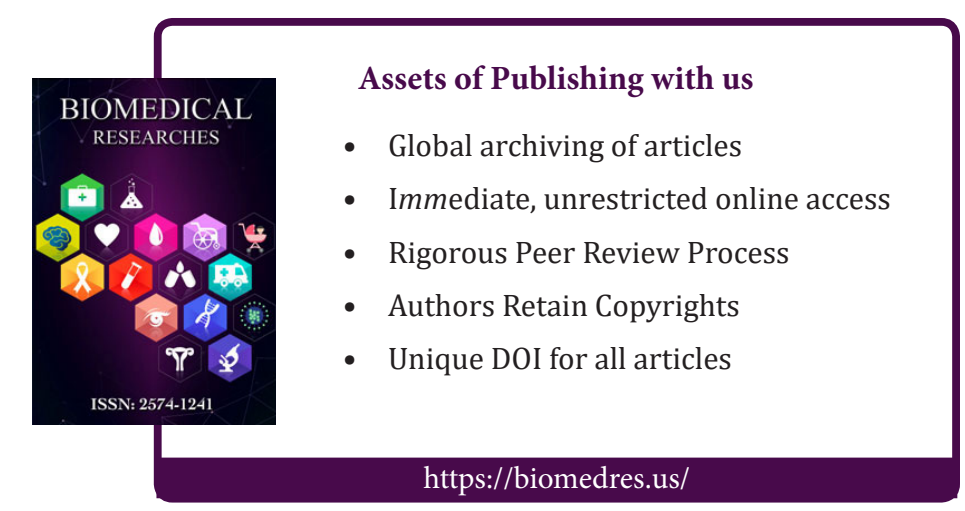

3. Gupta V, Monika Schmoll, Alfredo Herrera-Estrella, R Upadhyay, Irina Druzhinina Maria, et al. (2014) Biotechnology and Biology of Trichoderma.

4. Abu-Taleb M Amira, Kadriya El-Deeb, Fatimah O Al-Otibi (2011) Assessment of antifungal activity of Rumexvesicarius $L$. and Ziziphusspina-christi (L.) wild extracts against two phytopathogenic fungi. Afr J Microbiol Res 5(9): 1001-1011.

5. Council of Scientific and Industrial Research (CSIR), New Delhi, India. 